\title{
The Utilisation of Duolingo to Enhance the Speaking Proficiency of EFL Secondary School Students in Saudi Arabia
}

\author{
Sultan R Alfuhaid ${ }^{1}$ \\ ${ }^{1}$ Department of English Language and Translation, College of Arabic Language and Social Studies, Qassim \\ University, Buraydah, Saudi Arabia \\ Correspondence: Sultan R. Alfuhaid, Department of English Language and Translation, College of Arabic \\ Language and Social Studies, Qassim University, Buraydah, Saudi Arabia.
}

Received: September 5, 2021

Accepted: October 4, 2021

Online Published: October 8, 2021

doi: $10.5539 /$ elt.v14n11p9

URL: https://doi.org/10.5539/elt.v14n11p9

\begin{abstract}
Even though Saudi EFL students devote multiple years to improving their English-speaking proficiency, they struggle to achieve fluency. The present study, however, focuses on investigating the effectiveness of using Duolingo in EFL classrooms to enhance the participants' speaking proficiency. The participants who underwent this study were 28 male Saudi students studying in secondary school, namely at Sharia Institute. They were divided into control and experimental groups. Data was collected via post-test to conduct a valid comparison between the two groups. The 14 students in the experimental group had been using Duolingo for a period of four consecutive months while the participants in the control group have never used Duolingo. To make a valid comparison of the mean score between the two groups, an independent samples t-test was used in this experiment. After analysing the results, it has been concluded that the integration of Duolingo in the learning process has a fundamental positive impact on enhancing participants' speaking proficiency as well as improving their overall language skills. Additionally, the participants' positive attitude towards Duolingo was an intrinsic factor that helped alleviate their anxiety when speaking.
\end{abstract}

Keywords: CALL, CMC, Duolingo, L2 speaking proficiency, SLA

\section{Introduction}

\subsection{Speaking and EFL Saudi Students}

The fundamental skills of learning any language are basically reading, writing, listening and speaking. English is a language that is taught in Saudi Arabia at different levels. English textbooks in Saudi Arabia are designed to focus on the four skills of learning a language. Speaking, however, is overlooked in many English classes in Saudi Arabia; consequently, students encounter numerous difficulties with this skill (Altwairish, 2009). Indeed, Albureikan (2008) believed that students in Saudi Arabia struggle when speaking, and they barely produce well-structured sentences.

There are three vital factors that hinder Saudi EFL learners in improving their English proficiency. The first factor is associated with the learners' attitude and their educational background; the second is linked to the environment of the school; and the third is associated with teachers and textbooks (Hamouda, 2013). Lack of enthusiasm is another serious problem that Saudi EFL learners encounter (Alonayzan, 2015; Hamouda, 2013). Moreover, strategies that support the use of language in semi-authentic situations such as role-play are entirely overlooked by many Saudi teachers (Alharbi, 2015).

\subsection{The Significance of Integrating Technology in Teaching}

To increase learners' proficiency, teachers should consider integrating technology into their teaching process. Additionally, the process of using technology in language learning, which is known as computer-assisted language learning (CALL), can significantly help teachers. One of the most widely used applications of CALL is computer-mediated communication (CMC), which refers to the use of computer as a modern method to initiate communication among remote users (Guarda, 2012). Although social interaction is vital in learning languages, it is hugely restricted in Saudi Arabia; therefore, using technology to compensate for the lack of interaction is helpful in improving EFL students' language proficiency. Indeed, the use of an application that provides communication with natives to enhance speaking has become an alternative option for those who are unable to be in an 
English-speaking environment. This study sheds light on the influence of Duolingo on EFL students' speaking proficiency and seeks to answer the question of whether the integration of Duolingo into the learning process can help students improve their overall language proficiency.

\subsection{Research Hypothesis}

This study will test the following hypothesis:

1) The two groups will experience a huge difference in the mean scores of the post-test; that is, the experimental group will outperform the control group due to better English exposure.

\subsection{Significance of the Study}

This study has empirical, educational and national significance. Empirically, it adds to the literature about the employment of CMC and phone applications to enhance EFL students' speaking skills. Furthermore, this study tackles the issue of male Saudi EFL students' speaking deficiencies by investigating the influence of current methods of language learning using technology on their speaking skills. Educationally, this study is significant for both teachers and students. It provides teachers with ideas to move away from traditional methods of teaching to an innovative technique that is dependent upon technology. Additionally, learning applications could improve students' educational levels and encourage them to become self-directed learners.

A massive part of the Saudi yearly budget is designated to improving the field of education in general and maximising students' competence and skills in particular. In addition, one of the visions that the Saudi government hopes to achieve by 2030 is a stable and strong education system that allows for more upward mobility than in previous decades. This can be achieved by strengthening the educational level of Saudi schools and universities, developing Saudi curriculums, and enhancing Saudi students' proficiency levels. The use of techniques in EFL classes that improve Saudi students' speaking proficiency through the integration of technology to achieve an authentic use of English in daily live communication could indeed help to achieve such a vision. After enhancing their educational excellence, Saudi students will be more qualified to enter the labour market. Bygate (1987) posited that people are usually judged and professionally evaluated by their speaking proficiency. Thus, competent Saudi learners of English can participate more effectively in the labour market. This would reduce the number of unemployed people and the need for foreign workers in Saudi Arabia. Moreover, if advanced techniques that would enhance Saudi EFL students' English skills were adopted in Saudi EFL classes, government expenditures to aid struggling students would be reduced. Therefore, the integration of technology as well as successful methods of teaching are vital elements in achieving the Saudi 2030 vision.

\subsection{Definitions of Key Terms}

Duolingo: A versatile social platform that is designed especially for language learning, Duolingo can be downloaded on mobile phones. Furthermore, this application makes learning language fun because it depends totally on games and casual conversations. One of its primary uses is enabling students to call or interact with native English speakers.

CALL: Beatty (2010) defined CALL as a process in which language learning takes place through computers. This process involves either designed lessons or activities that promote the use of the language.

CMC: Beatty (2010) defined CMC as a process in which computer or other technological instruments are used as a means of communication between language learners. Even if the goal of such communication is not language learning or development, language is expected to be acquired or developed.

\section{Literature Review}

A number of studies have discussed the deficiency of EFL oral skills in Saudi Arabia. For instance, the majority of Saudi students struggle to speak English on a daily basis because Arabic is quite dominant in real-life situations. Indeed, Altwairish (2009) claimed that EFL students' proficiency level is not as high as expected compared to the extensive classes they take. However, some teachers do not engage or interact with students in the classroom and prefer to use Arabic throughout their interactions (Alharbi, 2015; Hamad, 2013). Teachers struggle in speaking activities because they lack the most appropriate methods to conduct such exercises. Hence, the difficulties of EFL students with respect to language skills, particularly speaking, are worthy of investigation. Moreover, the environment of Saudi Arabia usually ignores the use of English in real-life contexts (Baniabdelrahman, 2013). Some teachers' excessive concentration on grammar leads them to overlook other skills, like speaking, and is an undeniable factor in impairing students' overall proficiency. Indeed, Jallalah (2013) illustrated that the majority of students had a massive amount of grammatical knowledge, but they did not know how to accurately use it while speaking. 


\subsection{CMC in EFL Classes}

Oral CMC platforms can be used effectively to attain primary pedagogical goals (Terhune, 2016). In general, the possibility of using $\mathrm{CMC}$ to enhance pronunciation and improve conversation was a vital element in developing students' oral skills (Althunayan, 2013; Hung \& Huang, 2015; Tsukamoto et al., 2009; Wu et al., 2012). Authentic communication witnessed a dramatic increase when applying CMC (Van Nguyen, 2010). Amiri et al. (2012) revealed that the integration of technology into the learning process gave students more flexibility, making learning faster and easier. Moreover, CMC strengthened and improved students' engagement, outperforming traditional instruction (Wu et al., 2012). Tsukamoto et al. (2009) concluded that students' confidence increased when speaking in English on conference calls using Skype; consequently, they enjoyed the experience of speaking with native English speakers. Grimshaw and Cardoso (2018) used a mobile game to reduce the limitations that learners encounter and concluded that students who used this game outperformed those who did not in oral examinations. Furthermore, there is an intrinsic relationship between EFL students' speaking proficiency and the use of social media; multiple studies have tested the positive and negative influence of social applications on improving language proficiency (Hong, 2006; Terhune, 2016). Overall, using technology and online chatting motivated students and improved their English language proficiency (Terhune, 2016).

Nevertheless, the results of studies that investigate the effectiveness of CALL applications or CMC tools in language learning are not consistent. While some studies have supported the view that $\mathrm{CMC}$ tools can positively influence language development (Amiri et al., 2012; Hong, 2006; Terhune, 2016; Tsukamoto et al., 2009; Van Nguyen, 2010; Wu et al., 2012), other studies have revealed slightly different results. For instance, Ko (2012) claimed that learners developed oral skills due to the factors that surround the environment (task design) rather than the environment itself. Thus, this study will add to the literature by investigating a tool that provides EFL learners with opportunities to participate in online conversations with native speakers.

\section{Methodology}

\subsection{Design}

An experimental design was applied in this study, which included two main variables: a dependent variable Duolingo - and an independent variable - the students' speaking proficiency. An experimental design allowed for an investigation of the relationship, if any, between the use of Duolingo and the students' overall speaking proficiency.

\subsection{Instruments}

The study was conducted experimentally to evaluate the influence, if any, of a particular application called Duolingo on two dependent groups. The researcher conducted a post-test to evaluate and compare the speaking proficiency of the two groups. The speaking test was an extract from the students' textbook called 'Traveller 1'. The students started using Duolingo four months before the actual experiment was conducted, so a pre-test was not conducted. An independent samples t-test using SPSS was used to analyse data quantitatively. To analyse the participants' post-test, the researcher used a rubric adopted from Harris (1969). According to this rubric, five sub-skills related to speaking were evaluated: pronunciation, grammar, vocabulary, comprehension and fluency. For each sub-skill, the participant was awarded a score out of five, with a total possible score of 25.

\subsection{Participants}

The participants evaluated in this study were 28 male students from a secondary school located in Alqassim region, namely Sharia Institute. They were divided into experimental and control groups. The experimental group, who had been using Duolingo an hour daily for four consecutive months, included 14 students between the ages of 16 and 17. The control group consisted of 14 students of a similar age who studied in the same class as the experimental group but had not used Duolingo as a CMC tool. All participants were native Arabic speakers and were taught by the same teacher. Furthermore, they shared similar cultural and educational backgrounds.

\section{Results}

Prior to testing the main hypothesis of this study, the researcher generated descriptive statistics using SPSS. The mean and standard deviation of both groups' post-test scores are presented in Table 1. The average participant from the experimental group had a better score, namely 6 points, than a participant from the control group. 
Table 1. Post-test scores of the two groups

\begin{tabular}{lllll}
\hline $\begin{array}{l}\text { Group Statistics } \\
\text { Group }\end{array}$ & $\mathrm{N}$ & Mean & Std. Deviation & Std. Error Mean \\
\hline Experimental & 14 & 21.43 & 2.102 & .562 \\
Control & 14 & 15.36 & 2.499 & .668
\end{tabular}

To test the hypothesis and, therefore, evaluate the influence that Duolingo had on the experimental group's speaking proficiency, the researcher relied on an independent samples t-test via SPSS. Table 2 demonstrates the results of the independent samples t-test. Whenever the p-value approaches .000 , statistical differences arise between the experimental and control groups. That is, the experimental group's post-test scores are significantly higher than the control group.

Table 2. Independent samples t-test

\section{Independent Samples Test}

Levene's Test

for Equality of

Variances t-test for Equality of Means

\begin{tabular}{|c|c|c|c|c|c|c|c|c|c|}
\hline & & & & & & Mean & Std. Error & $\begin{array}{l}95 \% \mathrm{C} \\
\text { of the I }\end{array}$ & $\begin{array}{l}\text { nfidence Interva } \\
\text { ifference }\end{array}$ \\
\hline & $\mathrm{F}$ & Sig. & $\mathrm{T}$ & df & (2-tailed) & Difference & Difference & Lower & Upper \\
\hline $\begin{array}{l}\text { Equal variances } \\
\text { assumed }\end{array}$ & .184 & .672 & 6.956 & 26 & .000 & 6.071 & .873 & 4.277 & 7.865 \\
\hline $\begin{array}{l}\text { Equal variances not } \\
\text { assumed }\end{array}$ & & & 6.956 & 25.257 & .000 & 6.071 & .873 & 4.275 & 7.868 \\
\hline
\end{tabular}

\section{Discussion}

The results of the independent samples t-test demonstrate that using Duolingo is effective in improving the speaking proficiency of the individuals who integrated it into their learning process over a period of four consecutive months. Contrary to Ko's (2012) conclusions, the environment in this study played a massive role in improving the participants' oral skills. In fact, the participants in the experimental group were able to speak with full confidence, and their speaking fluency outperformed those who participated in the control group. One potential explanation for this difference is that the participants in the experimental group became accustomed to speaking English with natives, contributing to their lack of anxiety. The control group, however, could not develop oral skills because they lacked the opportunity to practice; therefore, their language anxiety increased as they spoke. These findings are compatible with the results of Tsukamoto et al. (2009).

When examining speaking sub-skills, the researcher observed major differences between the two groups. With respect to both fluency and vocabulary range, the participants in the experimental group used a different range of vocabulary fairly well compared to the control group. As a result, the participants in the experimental group were adept at finishing the task they were given. Conversely, the control group encountered some difficulties in connected speech. Furthermore, the participants in the control group stumbled over their words on many occasions, used certain words repeatedly and struggled to come up with alternatives. Moreover, crucial grammatical differences were observed between the experimental and control groups. Specifically, the participants in the experimental group employed well-formed sentences compared to the control group. One of the primary grammatical mistakes made by the participants from the control group was the exclusion of helping verbs (e.g., 'I happy today') due to negative transfer from Arabic to English. Overall, the disparity in language proficiency between the two groups was significant: the participants in the experimental group developed many aspects of their oral skills, whereas the control group encountered a number of challenges including ill-formed sentences, limited vocabulary and lack of confidence.

\section{Conclusion}

The primary goal of the current study was to explain the impact of integrating a CMC tool in the teaching process and to investigate whether a specific application, Duolingo, would improve EFL speaking levels. The researcher selected 28 male participants to undergo the experiment. They were divided into two groups: experimental and control. The experimental group included 14 participants who had been using Duolingo for 
four months, whereas the control group included the remaining participants, who did not use this app. The results indicated a significant improvement in the speaking proficiency of the experimental group. Indeed, the control group encountered multiple difficulties when compared to the experimental group. An enhancement of vocabulary range followed by an increase in confidence were the primary outcomes in the experimental group. Ultimately, the researcher deduced that integrating technology during the learning process is an intrinsic factor in improving EFL students' proficiency because traditional teaching methods were perceived in a negative way. Students' lack of interest could be tackled by integrating technology and utilising useful applications that could help students improve their overall language performance in various ways. Therefore, this study provides a good starting point for discussion and further research.

\subsection{Limitations of the Study}

The current study had many limitations that might have influenced the results. Considering the current global pandemic situation, the post-test was conducted virtually. Moreover, due to a shortage of time, the researcher could not include more participants and could not test the students' speaking proficiency before the experiment.

\section{References}

Albureikan, A. (2008). The effectiveness of CALL in the EFL Saudi female students' speaking skills at the College of Health Sciences [Unpublished master's thesis]. Al-Imam Mohammed Bin Saud Islamic University, Riyadh, Saudi Arabia.

Alharbi, H. A. (2015). Improving students' English speaking proficiency in Saudi public schools. International Journal of Instruction, 8(1), 105-116. https://doi.org/10.12973/iji.2015.818a

Alonayzan, A. (2015). The effect of using video blogs on the speaking performance among EFL university students [Unpublished master's thesis]. Al-Imam Mohammed Bin Saud Islamic University, Riyadh, Saudi Arabia.

Althunayan, A. (2013). Using the technique of retelling digital stories to improve grade one students' speaking skill [Unpublished master's thesis]. Al-Imam Mohammed Bin Saud Islamic University, Riyadh, Saudi Arabia.

Altwairish, B. (2009). The effect of the communicative approach on the listening and speaking skills of Saudi secondary school students: An experimental study [Unpublished master's thesis]. King Saud University, Riyadh, Saudi Arabia.

Amiri, E., Hashemy, S. A., \& Hayati, D. (2012). A study of the application of digital technologies in teaching and learning English language and literature. International Journal of Scientific \& Technology Research, 1(5), 103-107.

Baniabdelrahman, A. A. (2013). Effect of using internet tools on enhancing EFL students' speaking skill. Journal of Contemporary Research, 3(6), 79-87.

Beatty, K. (2010). Teaching and researching computer-assisted language learning. Routledge.

Bygate, M. (1987). Speaking. Oxford University Press.

Grimshaw, J., \& Cardoso, W. (2018). Activate space rats! Fluency development in a mobile game-assisted environment. Language Learning \& Technology, 22(3), 159-175. https://doi.org/10125/44662

Guarda, M. (2012). Computer-mediated communication and foreign language education. Journal of E-Learning and Knowledge Society, 8(3), 15-27.

Hamad, M. M. (2013). Factors negatively affect speaking skills at Saudi colleges for girls in the south. English Language Teaching, 6(12), 87-97. https://doi.org/10.5539/elt.v6n12p87

Hamouda, A. (2013). An exploration of causes of Saudi students' reluctance to participate in the English language classroom. International Journal of English Language Education, 1(1). https://doi.org/10.5296/ijele.v1i1.2652

Harris, D. P. (1969). Testing English as a second language. McGraw- Hill.

Hong, B. T. M. (2006). Teaching speaking skills at a Vietnamese university and recommendations for using CMC. Asian EFL journal, 14(2).

Hung, S.-T. A., \& Huang, H.-T. D. (2015). Video blogging and English presentation performance: A pilot study. Psychological Reports, 117(2), 614-630. https://doi.org/10.2466/11.PR0.117c20z6

Jallalah, M. (2013). The effect of task-based roleplay on the speaking skill of students in the University of Dammam: An applied study [Unpublished master's thesis]. King Saud University, Riyadh, Saudi Arabia. 
Ko, C. (2012). Can synchronous computer-mediated communication (CMC) help beginning-level foreign language learners speak? Computer Assisted Language Learning, 25(3), 217-236. https://doi.org/10.1080/09588221.2011.649483

Terhune, N. M. (2016). Language learning going global: Linking teachers and learners via commercial Skype-based CMC. Computer Assisted Language Learning, 29(6), 1071-1089. https://doi.org/10.1080/09588221.2015.1061020

Tsukamoto, M., Nuspliger, B., \& Senzaki, Y. (2009). Using Skype to connect a classroom to the world: Providing students an authentic language experience within the classroom. In CamTESOL conference on English language teaching: selected papers (Vol. 5, pp. 162-168).

Van Nguyen, L. (2010). Computer mediated collaborative learning within a communicative language teaching approach: A sociocultural perspective. The Asian EFL Journal Quarterly, 12(1), 202-233.

Wu, W. C. V., Marek, M., \& Yen, L. L. (2012). Promotion of EFL student motivation, confidence, and satisfaction via a learning spiral, peer-scaffolding, and CMC. International Journal of Computer-Assisted Language Learning and Teaching (IJCALLT), 2(3), 54-75. https://doi.org/10.4018/ijcallt.2012070104 


\section{Appendix A}

The speaking test rubric

\begin{tabular}{|c|c|c|}
\hline Components & Assessments & Score \\
\hline \multirow{5}{*}{ Pronunciation } & $\begin{array}{l}\text { The pronunciation is clear and quite understandable for elementary } \\
\text { students. }\end{array}$ & 5 \\
\hline & There are some pronunciation problems, but still quite understandable. & 4 \\
\hline & $\begin{array}{l}\text { Pronunciation problems necessitate listening and occasionally leads to a } \\
\text { misunderstanding. }\end{array}$ & 3 \\
\hline & $\begin{array}{l}\text { Very hard to understand because of pronunciation problems. Must } \\
\text { frequently be asked to repeat. }\end{array}$ & 2 \\
\hline & $\begin{array}{l}\text { Pronunciation problems so severe as to make speech virtually } \\
\text { unintelligible. }\end{array}$ & 1 \\
\hline \multirow{5}{*}{ Grammar } & Errors in grammar are quite rare. & 5 \\
\hline & There are a few grammatical errors but still intelligible. & 4 \\
\hline & $\begin{array}{l}\text { Make frequent errors grammar, and word order occasionally obscure } \\
\text { meaning. }\end{array}$ & 3 \\
\hline & Grammar and word order errors make comprehension difficult. & 2 \\
\hline & $\begin{array}{l}\text { Errors in grammar and word order so severe as to make speech virtually } \\
\text { unintelligible. }\end{array}$ & 1 \\
\hline \multirow{5}{*}{ Vocabulary } & Almost all vocabulary used are in proper use. & 5 \\
\hline & $\begin{array}{l}\text { Frequently uses inappropriate terms or must replace ideas but still } \\
\text { intelligible. }\end{array}$ & 4 \\
\hline & $\begin{array}{l}\text { Frequently uses the wrong word; conversation somewhat limited because } \\
\text { of inadequate vocabulary. }\end{array}$ & 3 \\
\hline & $\begin{array}{l}\text { Misuse of words and very limited vocabulary make comprehension quite } \\
\text { difficult. }\end{array}$ & 2 \\
\hline & $\begin{array}{l}\text { Vocabulary limitation so extreme as to make conversation virtually } \\
\text { impossible. }\end{array}$ & 1 \\
\hline \multirow{5}{*}{ Fluency } & $\begin{array}{l}\text { Able to use the language fluently, rare skips, and the speed of speech is at } \\
\text { the normal rate. }\end{array}$ & 5 \\
\hline & Speed of speech seems to be slightly affected by language problems. & 4 \\
\hline & Speed and fluency are rather strongly affected by language problems. & 3 \\
\hline & Usually hesitant; often forced into silence by language limitations. & 2 \\
\hline & $\begin{array}{l}\text { Speech is so halting and fragmentary as to make conversation virtually } \\
\text { impossible. }\end{array}$ & 1 \\
\hline \multirow{5}{*}{ Comprehension } & Understands most of what is said at average speed. & 5 \\
\hline & $\begin{array}{l}\text { Understands what is said at average speed, but occasional repetition may } \\
\text { be necessary. }\end{array}$ & 4 \\
\hline & Understands what is said at slower than average speed. & 3 \\
\hline & $\begin{array}{l}\text { Has great difficulty following what is said. Can comprehend only "social } \\
\text { conversation" spoken slowly and with frequent repetition. }\end{array}$ & 2 \\
\hline & Cannot be said to understand even simple conversational English. & 1 \\
\hline
\end{tabular}

\section{Copyrights}

Copyright for this article is retained by the author(s), with first publication rights granted to the journal.

This is an open-access article distributed under the terms and conditions of the Creative Commons Attribution license (http://creativecommons.org/licenses/by/4.0/). 